\title{
The Effect of Incorporation of Ferrite Nanoparticles on Compressive Strength and Resistivity of Self-Compacting Concrete
}

\author{
Mohamed A. Ahmed 1*, Yehia A. Hassanean², Kamal A. Assaf', Moustafa A. Shawkey ${ }^{1}$ \\ ${ }^{1}$ Materials Science Lab. (1), Physics Department, Faculty of Science, Cairo University, Giza, Egypt \\ ${ }^{2}$ Department of Civil Engineering, Assiut University, Assiut, Egypt \\ Email: ${ }^{*}$ moala47@hotmail.com
}

Received 22 February 2015; accepted 12 March 2015; published 17 March 2015

Copyright (C) 2015 by authors and Scientific Research Publishing Inc.

This work is licensed under the Creative Commons Attribution International License (CC BY). http://creativecommons.org/licenses/by/4.0/

(c) (i) Open Access

\begin{abstract}
Mn-Ferrite nanoparticles were prepared using citrate auto combustion method. The prepared sample was characterized by X-ray diffraction (XRD), HRTEM and BET to measure the particle diameter and the surface area of the prepared sample. The data of XRD clarified that the sample was formed in single phase spinel structure without any extra peaks indicating non-existence of any secondary phase. The HRTEM micrograph indicated that the particles were in an agglomerated state due to the absence of surfactant and high magnetic properties of Mn-Ferrite nanoparticles. The mechanical properties were measured at different ratios of nano-Ferrite to concrete. The obtained values of mercury intrusion porosimetry (MIP) indicated that the addition of Mn-Ferrite nanoparticles increased the compressive strength and decreased the total intrusion volume. This was due to the rapid consuming of $\mathrm{Ca}(\mathrm{OH})_{2}$ which was formed during hydration of Portland cement especially at early ages due to the high reactivity of $\mathrm{MnFe}_{2} \mathrm{O}_{4}$ nanoparticles. Moreover, $\mathrm{MnFe}_{2} \mathrm{O}_{4}$ nanoparticles recovered the particle packing density of the blended cement, leading to a reduced volume of pores in the cement paste.
\end{abstract}

\section{Keywords}

Compressive Strength, Concrete, XRD, HRTEM, Reactivity

\section{Introduction}

Concrete is the most commonly and widely used as construction material in the entire world. It is actually

"Corresponding author.

How to cite this paper: Ahmed, M.A., Hassanean, Y.A., Assaf, K.A. and Shawkey, M.A. (2015) The Effect of Incorporation of Ferrite Nanoparticles on Compressive Strength and Resistivity of Self-Compacting Concrete. Open Journal of Civil Engineering, 5, 131-138. http://dx.doi.org/10.4236/ojce.2015.51013 
unique in construction as it is the only material exclusive to the business and therefore is the beneficiary of a fair proportion of the research and development money from industry [1]. Self compacting concretes (SCCs) are characterized by high packing densities which can be achieved with enhancement of grain size distribution by incorporating a homogeneous gradient of fine and coarse particles leading to improvement in the concrete mix [2] [3].

The understanding of the structure and behavior of concrete at the fundamental stage is a necessary and very appropriate use of nanotechnology. One of the fundamental aspects of nanotechnology is its interdisciplinary nature [1]. Concrete is a macro-material strongly influenced by its nano-properties and understanding it at this new level is opening new era for improvement the mechanical properties of concrete [4].

However, one of the advantages made by the study of concrete at the nanoscale is that particle packing in concrete can be improved by using $\mathrm{MnFe}_{2} \mathrm{O}_{4}$ nanoparticles leading to an enhancement of densification of the micro and nanostructure resulting in improved mechanical properties. $\mathrm{MnFe}_{2} \mathrm{O}_{4}$ nanoparticles addition to cement based materials can also control the formation of the fundamental calcium silicate hydrate (C-S-H) reaction of concrete caused by calcium leaching in water as well as block water penetration and therefore lead to improvements in durability [5].

Previously, several works have been conducted on concrete composites by adding different nanoparticles evaluating the mechanical properties of concrete. The activity of nanoparticles can act as heterogeneous nuclei for cement pastes, further accelerating cement hydration, as nanoreinforcement, and as nano filler, densifying the microstructure, leading to a reduced porosity [6].

The aim of this study is incorporating $\mathrm{MnFe}_{2} \mathrm{O}_{4}$ nanoparticles into SCCs to examine compressive strength of self-compacting concrete. In addition, pore structure and microstructure of the concrete specimens will be evaluated. Several specimens with a constant amount of polycarboxylate superplasticizer (PC) will be prepared and their physical and mechanical properties will be measured for different partial substitutions of $\mathrm{MnFe}_{2} \mathrm{O}_{4}$ nanoparticles to the cement paste [7].

When Ferrite nanoparticles are added to cement/concrete, they act as filler to fill the pores between cement particles resulting in finer pore structure. Also, more C-S-H gel can be formed in concrete due to the reaction that occurs between the Ferrite nanoparticles and the $\mathrm{Ca}(\mathrm{OH})_{2}$ in the hydrating of cement [8].

$\mathrm{MnFe}_{2} \mathrm{O}_{4}$ nanoparticles have been found to improve compressive strength of concrete, to increase resistance of failure and turn control the leaching of calcium, in addition, promote the hydration reactions of tricalcium silicate $\left(\mathrm{C}_{3} \mathrm{~S}\right)$ as a result of the large and highly reactive surface of the nanoparticles [4].

Addition of $0.5 \% \mathrm{MnFe}_{2} \mathrm{O}_{4}$ nanoparticles with dispersing agents has been observed to increase the compressive strength of concrete composites after 28 days by as much as $22 \%$.

\section{Materials and Methods}

\subsection{Materials and Mixtures}

\subsubsection{Cement}

Ordinary Portland Cement (OPC) grade (CEM I 52.5N) obtained from AL-Areash Cement Manufacturing Company of Egypt conforming to the British standard BS 12/1996 [9] was used as received. The chemical properties of the cement are obtained from Pnalytical Axios Advanced X-ray fluorescence (XRF) and the results are reported in Table 1.

\subsection{2. $\mathrm{MnFe}_{2} \mathrm{O}_{4}$ Nanoparticles}

$\mathrm{MnFe}_{2} \mathrm{O}_{4}$ nanoparticles with average diameter of $49 \mathrm{~nm}$ and average surface area of $27.28 \mathrm{~m}^{2} / \mathrm{g}$ was prepared by citrate nitrate auto combustion method at Materials Science Lab. (1) [10] [11]. The properties of $\mathrm{MnFe}_{2} \mathrm{O}_{4}$ nanoparticles are shown in Table 2. High-resolution transmission electron microscopy (HRTEM) and powder X-ray diffraction (XRD) diagrams of $\mathrm{MnFe}_{2} \mathrm{O}_{4}$ nanoparticles are shown in Figure 1 and Figure 2, respectively.

Table 1. Properties of Portland cement (wt\%).

\begin{tabular}{ccccccccccccc}
\hline $\mathrm{Al}_{2} \mathrm{O}_{3}$ & $\mathrm{SiO}_{2}$ & $\mathrm{CaO}$ & $\mathrm{TiO}_{2}$ & $\mathrm{Na}_{2} \mathrm{O}$ & $\mathrm{MgO}$ & $\mathrm{SO}_{3}$ & $\mathrm{~K}_{2} \mathrm{O}$ & $\mathrm{Fe}_{2} \mathrm{O}_{3}$ & $\mathrm{~L}_{.} \mathrm{O} . \mathrm{I}$ \\
\hline 4.46 & 15.15 & 66.89 & 0.37 & 0.58 & 0.58 & 4.02 & 0.22 & 4.49 & 3.24 \\
\hline
\end{tabular}


Table 2. Properties of $\mathrm{MnFe}_{2} \mathrm{O}_{4}$ nanoparticles.

\begin{tabular}{ccc}
\hline Average diameter/nm & Average surface area/(m²/g) & Average volume/(cc/g) \\
\hline 49 & 27.28 & 0.0134 \\
\hline
\end{tabular}

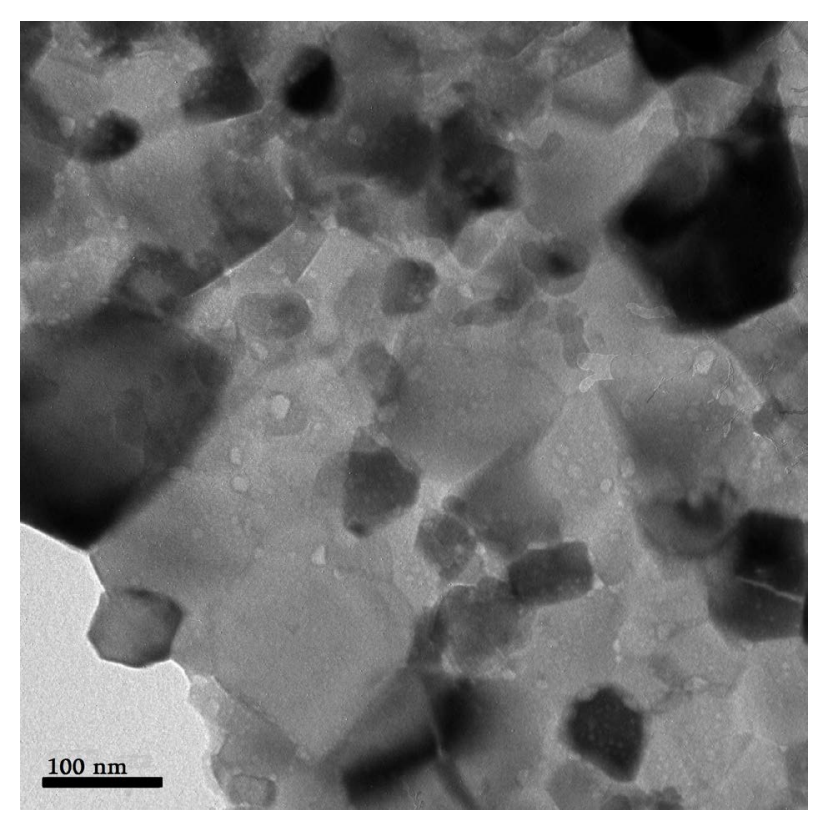

Figure 1. HRTEM micrograph of $\mathrm{MnFe}_{2} \mathrm{O}_{4}$ nanoparticles.

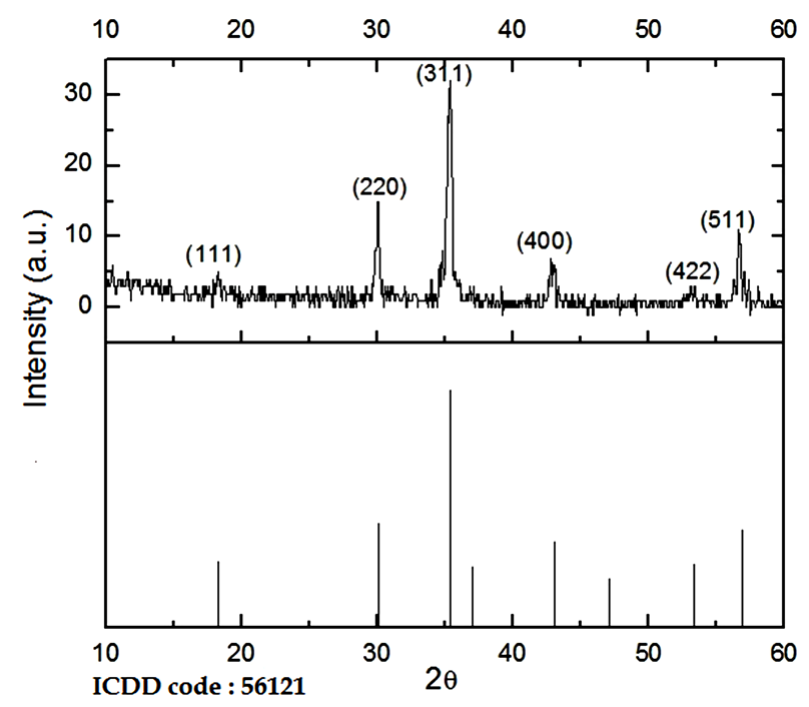

Figure 2. XRD analysis of $\mathrm{MnFe}_{2} \mathrm{O}_{4}$ nanoparticles.

\subsubsection{Aggregates}

Crushed limestone aggregates $(4.75$ - $12.5 \mathrm{~mm})$ were used to produce self-compacting concretes, with gravel (12.5 - $22 \mathrm{~mm})$ and coarse sand (0.5 - $2 \mathrm{~mm})$.

\subsubsection{Superplasticizer}

Sika ViscoCrete ${ }^{\circledR}-5930$ is an aqueous solution of modified polycarboxylate was used. Table 3 reports some of the physical and chemical properties of polycarboxylate admixture used in this study. 
Table 3. Physical and chemical characteristics of the superplasticizer admixture.

\begin{tabular}{ccccc}
\hline Appearance & Colour & Specific gravity/(kg/L) & $\mathrm{Na}^{+} \mathrm{Ppm}$ & $\mathrm{Ca}^{+} \mathrm{Ppm}$ \\
\hline Turbid liquid & Yellow-brown & $1.08 \pm 0.005$ & 18380 & 4.72 \\
\hline
\end{tabular}

\subsubsection{Mixture Proportioning}

Two series of mixtures were prepared in the laboratory trials as shown in Table 4. C0-SCC mixtures were prepared as control specimens. The control mixtures were made of natural aggregates, cement and water. $\mathrm{N}$ series were prepared with different concentrations of $\mathrm{MnFe}_{2} \mathrm{O}_{4}$ nanoparticles with average diameter of $49 \mathrm{~nm}$. The mixtures were prepared with the nanoparticles replacement of $0.5 \%, 1.0 \%, 1.5 \%$ and $2.0 \%$ by weight of cement and $0.5 \mathrm{wt} \%$ polycarboxylate admixture. The superplasticizer was dissolved in water, and then the $\mathrm{MnFe}_{2} \mathrm{O}_{4}$ nanoparticles were added and good stirred at a high speed for $2 \mathrm{~min}$. The aggregates for the mixtures consisted of a combination of Crushed limestone, gravel and sand. The binder content of all mixtures was $650 \mathrm{~kg} / \mathrm{m}^{3}$. The total mixing time including homogenizing was 5 minutes.

\subsection{Strength Evaluation Tests}

Cubic specimens with $100 \mathrm{~mm}$ edge length were used for compressive tests [5]. The moulds were covered with polyethylene sheets and moistened for $24 \mathrm{~h}$. Then the specimens were demoulded and cured in water at room temperature prior to test days [4]. The strength tests of the specimens were determined after 7 and 28 days of curing. Compressive tests were carried out according to the ASTM C 39 [12] standard. The tests were carried out triplicately and average strength values were obtained.

\subsection{Mercury Intrusion Porosimetry (MIP)}

MIP Poresizer 9320 V2.08 was used to characterize the pore structure in porous material as a result of its simplicity, quickness and wide measuring range of pore diameter [13] [14]. MIP gives us details about the dimensions of pores [13]. To prepare the specimens for MIP measurement, the concrete specimens after 28 days of curing were first broken into smaller pieces, and then the cement paste fragments selected from the center of prisms were used to measure pore structure. The specimens were immersed in acetone to stop hydration as fast as possible. Before mercury intrusion test, the specimens were dried in an oven at about $110^{\circ} \mathrm{C}$ until constant weight is obtained by removing moisture in the pores. MIP is based on the assumption that the non wetting liquid mercury (the contact angle between mercury and solid is greater than $90^{\circ}$ ) will only intrude in the pores of porous material under pressure [13] [14]. Each pore size is quantitatively determined from the relationship between the volume of intruded mercury and the applied pressure [11]. The test apparatus used for pore structure measurement is Auto Pore III mercury porosimeter. The surface tension of mercury is taken as $485 \times 10^{-5} \mathrm{~N} / \mathrm{cm}$ (485 dyne/cm), and the contact angle selected is $130 \mathrm{deg}$. The maximum head pressure applied is (4.68 psi).

\subsection{Thermogravimetric Analysis (TGA) and Derivative Thermogravimetry (DTG)}

A Netzsch STA 409 simultaneous thermal analyzer was used to measure the weight loss of the specimens. Specimens which were cured for 28 days were heated to $650^{\circ} \mathrm{C}$, at a heating rate of $4^{\circ} \mathrm{C} / \mathrm{min}$ and in an inert $\mathrm{N}_{2}$ atmosphere.

\subsection{Scanning Electron Microscopy (SEM)}

SEM investigations were conducted on a Hitachi Model S-3700N CD-SEM apparatus. Backscattered electron (BSE) and secondary electron (SE) imaging was used to study the specimens, which were prepared under conditions that ensured their subsequent viability for analytical purposes.

\section{Results and Discussion}

Table 5 shows the compressive strength of C0-SCC and N-SCC specimens after 7 and 28 days of curing. The results show that the compressive strength increases by adding $\mathrm{MnFe}_{2} \mathrm{O}_{4}$ nanoparticles by $0.5 \mathrm{wt} \%$ replacements and then it decreases. $\mathrm{MnFe}_{2} \mathrm{O}_{4}$ nanoparticles accelerate consumption of crystalline $\mathrm{Ca}(\mathrm{OH})_{2}$ which quickly are 
Table 4. Mix proportion of samples.

\begin{tabular}{|c|c|c|c|c|c|c|c|c|c|}
\hline \multirow{2}{*}{$\begin{array}{l}\text { Sample } \\
\text { name }\end{array}$} & \multirow{2}{*}{$\begin{array}{c}\mathrm{MnFe}_{2} \mathrm{O}_{4} \\
\text { nanoparticles/\% }\end{array}$} & \multirow{2}{*}{$\begin{array}{c}\text { SP content } \\
/ \%\end{array}$} & \multicolumn{7}{|c|}{ Quantities $/\left(\mathrm{kg} / \mathrm{m}^{3}\right)$} \\
\hline & & & Water & SP & Sand & Gravel & $\begin{array}{l}\text { Crushed } \\
\text { limestone }\end{array}$ & Cement & $\begin{array}{c}\mathrm{MnFe}_{2} \mathrm{O}_{4} \\
\text { nanoparticles }\end{array}$ \\
\hline C0 & 0 & 0.5 & 180 & 3.25 & 580 & 580 & 580 & 650 & 0 \\
\hline N1 & 0.5 & 0.5 & 180 & 3.25 & 580 & 580 & 580 & 646.75 & 3.25 \\
\hline N2 & 1 & 0.5 & 180 & 3.25 & 580 & 580 & 580 & 643.5 & 6.5 \\
\hline N3 & 1.5 & 0.5 & 180 & 3.25 & 580 & 580 & 580 & 640.25 & 9.75 \\
\hline N4 & 2 & 0.5 & 180 & 3.25 & 580 & 580 & 580 & 637 & 13 \\
\hline
\end{tabular}

Table 5. Compressive strength of C0-SCC and N-SCC specimens.

\begin{tabular}{|c|c|c|c|}
\hline Sample name & $\mathrm{MnFe}_{2} \mathrm{O}_{4}$ nanoparticles/\% & $\begin{array}{c}\text { Compressive } \\
7 \text { days }\end{array}$ & $\begin{array}{c}\text { strength/MPa } \\
28 \text { days }\end{array}$ \\
\hline $\mathrm{CO}$ & 0 & 52.7 & 56.4 \\
\hline N1 & 0.5 & 65.3 & 68.9 \\
\hline N2 & 1 & 62.6 & 64.3 \\
\hline N3 & 1.5 & 51.5 & 56.3 \\
\hline N4 & 2 & 49.2 & 68.9 \\
\hline
\end{tabular}

formed into C-S-H during hydration of cement specially at early ages due to the high reactivity of these nanoparticles. As a consequence, larger volumes of reaction products are formed. Moreover, $\mathrm{MnFe}_{2} \mathrm{O}_{4}$ nanoparticles act as filler for strengthening the micro structure of cement. They reduce the quantity and size of $\mathrm{Ca}(\mathrm{OH})_{2}$ crystals and fill the voids of C-S-H gel structure to make the structure of hydrated product more compact [15].

However, increasing $\mathrm{MnFe}_{2} \mathrm{O}_{4}$ nanoparticles more than $0.5 \mathrm{wt} \%$, the compressive strength reduces. This is because the amount of $\mathrm{MnFe}_{2} \mathrm{O}_{4}$ nanoparticles present in the mix is higher than the amount required to combine with the liberated lime during the process of hydration. This leads to an excess of silica leaching out and causes degradation in strength. Though, nanoparticles replace part of the cementitious material but don't contribute in the reaction. Also, cracks generated in dispersion of nanoparticles cause weak zones [16] [17].

In other words, this phenomenon can be explained by the assumption that nanoparticles are uniformly distributed in concrete and each particle is contained in a cube pattern. Therefore, the distance between nanoparticles can be determined. After the beginning of hydration process, hydrate products diffuse and envelop nanoparticles as kernel [6] [15].

When the amount of nanoparticles and the distances between them are appropriate, they can accelerate C-S-H gel formation as a result of increased crystalline $\mathrm{Ca}(\mathrm{OH})_{2}$ amount at the early age of hydration due to their high reactivity, and hence the compressive strength of concrete increases. With excessive increase of $\mathrm{MnFe}_{2} \mathrm{O}_{4}$ nanoparticles, the distance between them decreases and $\mathrm{Ca}(\mathrm{OH})_{2}$ crystals required for C-S-H gel formation don't grow up enough due to limited space and therefore, the formation of $\mathrm{Ca}(\mathrm{OH})_{2}$ crystals is hindered. The result of this process is the increase in shrinkage and creep of concrete mix and decreasing the compressive strength [6].

The mercury intrusion results of the C0-SCC specimen and N1-SCC specimen are shown in Figure 3 and Figure 4. Figure 3 represents the variation of incremental intrusion, reflecting pore volume against pore diameter, which indicates that most pore diameter of the specimen are distributed between 0.1 micrometer to $1 \mathrm{mi}$ crometer. Figure 4 represents the cumulative intrusion, reflecting the total connected pore volume of pore sizes. Table 6 shows that by increasing $\mathrm{MnFe}_{2} \mathrm{O}_{4}$ nanoparticles by $0.5 \mathrm{wt} \%$, total intrusion volume of specimens of concrete are decreased. This leads to decreasing total pore area and median pore diameter (area), but median pore diameter (volume) of these specimens is increased.

On the other hand, Table 7 shows that the addition of $\mathrm{MnFe}_{2} \mathrm{O}_{4}$ nanoparticles by $0.5 \mathrm{wt} \%$ leads to decreasing the porosity, increase the average pore diameter and decreasing the bulk density and the apparent (skeletal) density of these specimens of concrete. This means the regularity of porosity is similar to that of total intrusion vo- 

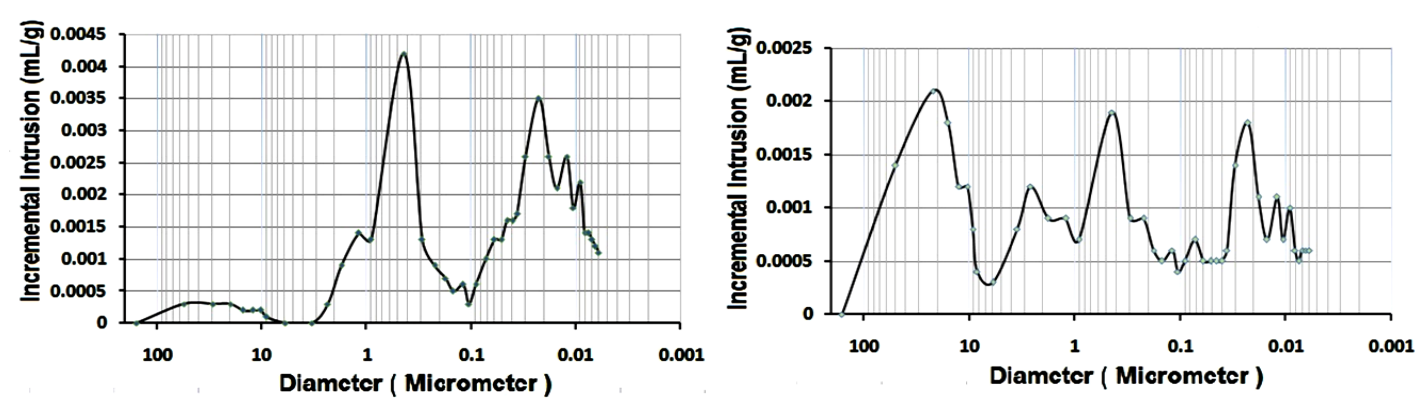

Figure 3. Incremental intrusion versus diameter for specimens of concrete (left: C0, right: N1).
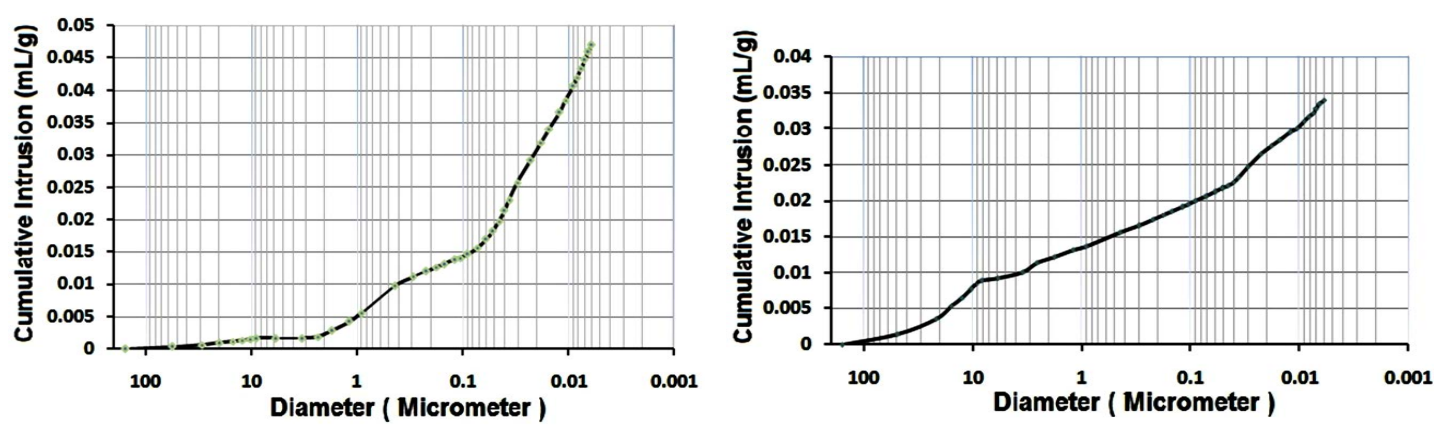

Figure 4. Cumulative intrusion versus diameter for specimens of concrete (left: C0, right: N1).

Table 6. Total intrusion volume, total pore area, median pore diameter (volume) and media pore diameter (area) of C0-SCC and N1-SCC specimens.

\begin{tabular}{ccccc}
\hline Sample name & $\begin{array}{c}\text { Total intrusion } \\
\text { volume/(mL/g) }\end{array}$ & Total pore area $/\left(\mathrm{m}^{2} / \mathrm{g}\right)$ & $\begin{array}{c}\text { Median pore diameter } \\
\text { (volume)/nm }\end{array}$ & $\begin{array}{c}\text { Median pore diameter } \\
(\text { area }) / \mathrm{nm}\end{array}$ \\
\hline $\mathrm{C} 0$ & 0.048 & 8.48 & 35.1 & 10.4 \\
$\mathrm{~N} 1$ & 0.034 & 3.80 & 251.4 & 10.1 \\
\hline
\end{tabular}

Table 7. Average pore diameter, bulk density, apparent (skeletal) density and porosity of C0-SCC and N1-SCC specimens.

\begin{tabular}{ccccc}
\hline Sample name & $\begin{array}{c}\text { Average pore } \\
\text { diameter/nm }\end{array}$ & Bulk density/(g/mL) & $\begin{array}{c}\text { Apparent (skeletal) } \\
\text { density/(g/mL) }\end{array}$ & Porosity/\% \\
\hline C0 & 22.2 & 2.64 & 3.02 & 12.40 \\
N1 & 35.8 & 2.43 & 2.65 & 8.26 \\
\hline
\end{tabular}

lume and the regularity of average pore diameter is similar to median diameter (volume). The increase of average pore diameter and median diameter (volume) are due to the ability of $\mathrm{MnFe}_{2} \mathrm{O}_{4}$ nanoparticles to fill the small pores. Also, the decrease of density is due to the replacement of cement by $\mathrm{MnFe}_{2} \mathrm{O}_{4}$ nanoparticles which have a lower density leading to a decrease in the density of the composite.

The thermal results of the C0-SCC specimen and N1-SCC specimen are shown in Figure 5 which displays two lines. The solid line represents the thermogravimetric analysis and the dashed line represents the derivative thermogravimetry. It is clear that TGA curves for these pastes consist of three zones. The first weight loss zone usually includes capillary pore water, interlayer water and adsorbed water. The second weight loss zone includes dehydration of calcium silicate hydrates and the third zone includes the dehydration of CH. Following chemical reaction usually takes place in the third zone:

$$
\mathrm{Ca}(\mathrm{OH})_{2} \rightarrow \mathrm{CaO}+\mathrm{H}_{2} \mathrm{O}
$$

The TGA/DTG results clarify a reduction in the calcium hydroxide $(\mathrm{CH})$ content in specimen N1-SCC compared to specimen C0-SCC which confirms the improvement of mechanical properties and occurrence of poz- 
zolanic reaction after 28 days of hydration.

Table 8 shows the thermogravimetric analysis results of C0-SCC and N1-SCC specimens measured to $650^{\circ} \mathrm{C}$ in which dehydration of the hydrated products occurred. The results show that after 28 days of curing, the loss in weight of the specimens is decreased by increasing $\mathrm{MnFe}_{2} \mathrm{O}_{4}$ nanoparticles in concretes by $0.5 \mathrm{wt} \%$. The decrease in loss weight is due to more formation of C-S-H compounds in the cement paste [4].

Finally, Figure 6 shows the SEM micrographs of C0-SCC specimen (control specimen) and N1-SCC specimen containing $0.5 \mathrm{wt} \% \mathrm{MnFe}_{2} \mathrm{O}_{4}$ nanoparticles cured for 28 days. The morphological analysis of C0-SCC specimen shows clearly the presence of large pores. On the other hand, the morphological analysis shows that specimen reinforced with $\mathrm{MnFe}_{2} \mathrm{O}_{4}$ nanoparticles with $0.5 \mathrm{wt} \%$ is more compact and less porous in the paste with admixture than the control one. In spite of this, both reactions are observed to progress, with a considerable decrease in the amount of anhydrous cement particles which indicates rapid formation of C-S-H gel, especially in the presence of $\mathrm{MnFe}_{2} \mathrm{O}_{4}$ nanoparticles.

\section{Conclusions}

The obtained results can be summarized as follows:

1) The results showed that concrete specimen reinforced with $\mathrm{MnFe}_{2} \mathrm{O}_{4}$ nanoparticles had higher compressive strength compared to that of the concrete without $\mathrm{MnFe}_{2} \mathrm{O}_{4}$ nanoparticles. It was found that the cement could be advantageously doped with $\mathrm{MnFe}_{2} \mathrm{O}_{4}$ nanoparticles up to maximum limit of $1 \%$ by weight of cement
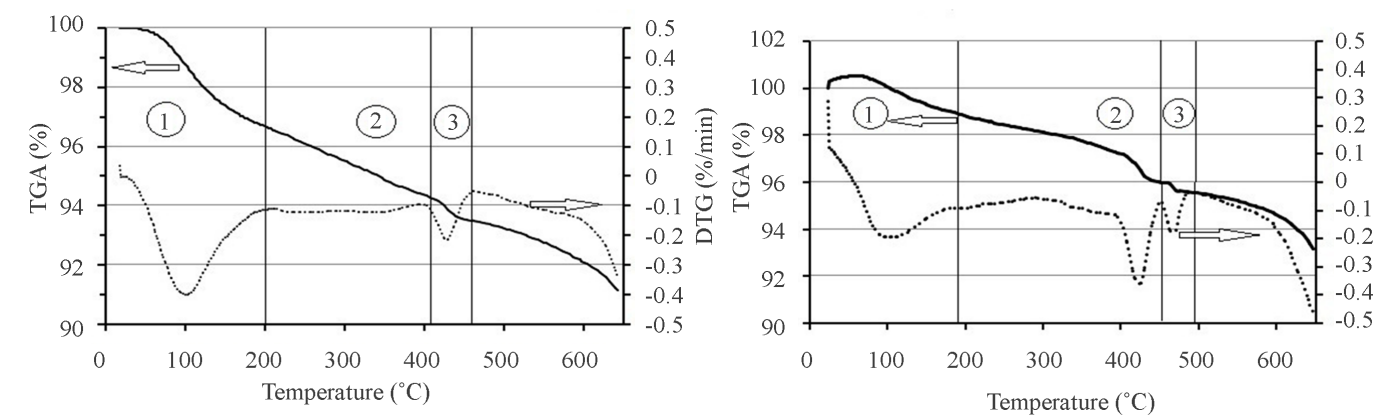

Figure 5. TGA /DTG profiles of specimens of concrete after 28 days of curing (left: C0, right: N1).
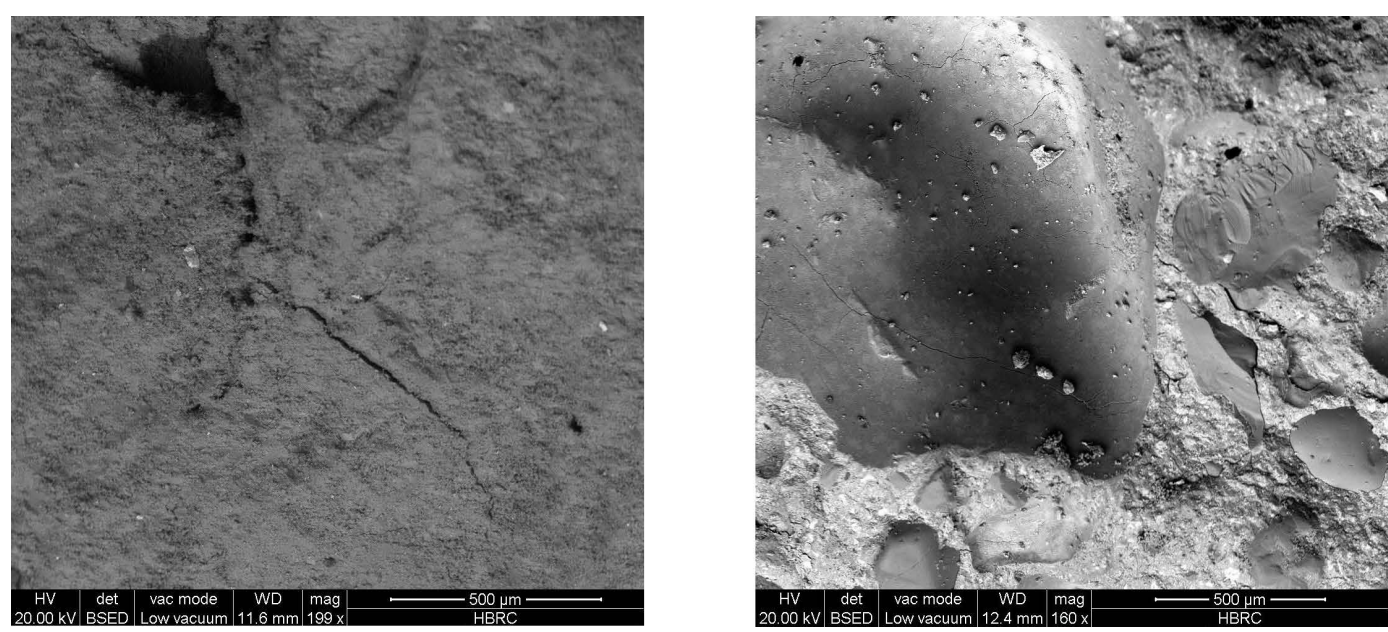

Figure 6. SEM micrograph of specimens of concrete after 28 days of curing (left: C0, right: N1).

Table 8. Weight loss (\%) of the pastes in the range to $650^{\circ} \mathrm{C}$ after 28 days of curing of C0-SCC and N1-SCC specimens.

\begin{tabular}{cc}
\hline Sample name & Total weight loss/\% \\
\hline C0 & 8.77 \\
N1 & 7.06 \\
\hline
\end{tabular}


with average diameter of $49 \mathrm{~nm}$. However, the maximum value of compressive strength was achieved with $0.5 \mathrm{wt} \%$ doped $\mathrm{MnFe}_{2} \mathrm{O}_{4}$ nanoparticles. The addition of $\mathrm{MnFe}_{2} \mathrm{O}_{4}$ nanoparticles with $1.5 \mathrm{wt} \%$ and $2 \mathrm{wt} \%$ led to a compressive strength lower than the control specimen.

2) The pore structure of self-compacting concrete containing $\mathrm{MnFe}_{2} \mathrm{O}_{4}$ nanoparticles was improved and the volume of all mesopores and macropores was decreased.

3) Thermogravimetric analysis showed that $\mathrm{MnFe}_{2} \mathrm{O}_{4}$ nanoparticles decreased the weight loss of the specimens when they were added to concrete with $0.5 \mathrm{wt} \%$. More rapid formation of hydrated products in the presence of $\mathrm{MnFe}_{2} \mathrm{O}_{4}$ nanoparticles which was confirmed by these results could be the reason for minimizing weight loss.

4) SEM images showed that specimen reinforced with $\mathrm{MnFe}_{2} \mathrm{O}_{4}$ nanoparticles with $0.5 \mathrm{wt} \%$ was more compact and less porous in the paste with admixture than the control one.

\section{Acknowledgements}

The authors would like to thank Dr. M. K. Abdelmaksoud and Dr. S. I. El-Dek for practical support in Materials Science Lab. (1), physics Department, Faculty of science, Cairo University, Giza, Egypt.

\section{References}

[1] Soleymani, F. (2012) Computer-Aided Prediction of Physical and Mechanical Properties of High Strength Concrete Containing $\mathrm{Fe}_{2} \mathrm{O}_{3}$ Nanoparticles. The Journal of American Science, 8, 338-345.

[2] Tyson, B., Abu Al-Rub, R., Yazdanbakhsh, A. and Grasley, Z. (2011) Carbon Nanotubes and Carbon Nanofibers for Enhancing the Mechanical Properties of Nanocomposite Cementitious Materials. Journal of Materials in Civil Engineering, 23, 1-8. http://dx.doi.org/10.1061/(ASCE)MT.1943-5533.0000266

[3] Al-Salami, A.E., Al-Assiri, M.S., Al-Hajry, A., Ahmed, M.A. and Taha, S. (2007) The Effect of Curing Time and Porosity on the Microstructure Hydrated Products in Some Blended Cement Pastes. Silicate Industrial, 72, 163.

[4] Khoshakhlagh, A., Nazari, A. and Khalaj, G. (2012) Effects of $\mathrm{Fe}_{2} \mathrm{O}_{3}$ Nanoparticles on Water Permeability and Strength Assessments of High Strength Self-Compacting Concrete. Journal of Materials Science Technology, 28, 7382. http://dx.doi.org/10.1016/S1005-0302(12)60026-7

[5] Nazari, A. and Riahi, S. (2010) The Effects of $\mathrm{ZrO}_{2}$ Nanoparticles on Physical and Mechanical Properties of High Strength Self Compacting Concrete. Materials Research, 13, 551-556. http://dx.doi.org/10.1590/S1516-14392010000400019

[6] Nazari, A., Riahi, S., Shamekhi, S. and Khademno, A. (2010) The Effects of Incorporation $\mathrm{Fe}_{2} \mathrm{O}_{3}$ Nanoparticles on Tensile and Flexural Strength of Concrete. The Journal of American Science, 6, 90-93.

[7] Nazari, A. and Riahi, S. (2011) Effects of CuO Nanoparticles on Compressive Strength of Self-Compacting Concrete. Indian Academy of Sciences, 36, 371-391.

[8] Chung, D.D.L. (2004) Cement-Matrix Structural Nanocomposites. Metals and Materials, 10, 55-67. http://dx.doi.org/10.1007/BF03027364

[9] British Standard Institution, BS 12 (1996) Specifications for Portland Cement. BSI, London.

[10] Ahmed, M.A., Bishay, S.T. and El-Dek, S.I. (2012) Characteristics of $\mathrm{Dy}_{2.8} \mathrm{Sr}_{0.2} \mathrm{Fe}_{5} \mathrm{O}_{12}$ Garnet (DySrIG). The European Physical Journal Applied Physics, 59, Article No. 20401. http://dx.doi.org/10.1051/epjap/2012110465

[11] Ahmed, M.A., Okasha, N. and El-Dek, S.I. (2008) Preparation and Characterization of Nanometric Mn Ferrite via Different Methods. Nanotechnology, 19, 6. http://dx.doi.org/10.1088/0957-4484/19/6/065603

[12] ASTM C39 (2001) Standard Test Method for Compressive Strength of Cylindrical Concrete Specimens. ASTM, Philadelphia.

[13] Abell, A., Willis, K. and Lange, D. (1999) Mercury Intrusion Porosimetry and Image Analysis of Cement-Based Materials. Journal of Colloid and Interface Science, 211, 39. http://dx.doi.org/10.1006/jcis.1998.5986

[14] Tanaka, K. and Kurumisawa, K. (2002) Development of Technique for Observing Pores in Hardened Cement Paste. Cement and Concrete Research, 32, 1435. http://dx.doi.org/10.1016/S0008-8846(02)00806-2

[15] Yazdi, N., Arefi, M., Mollaahmadi, E. and Nejand, B. (2011) To Study the Effect of Adding $\mathrm{Fe}_{2} \mathrm{O}_{3}$ Nanoparticles on the Morphology Properties and Microstructure of Cement Mortar. Life Science Journal, 8.

[16] Li, H., Zhang, M.H. and Ou, J.P. (2006) Abrasion Resistance of Concrete Containing Nano-Particles for Pavement. Wear, 260, 1262-1266. http://dx.doi.org/10.1016/j.wear.2005.08.006

[17] Meng, T., Yu, Y., Qian, X., Zhan, S. and Qian, K. (2012) Effect of Nano- $\mathrm{TiO}_{2}$ on the Mechanical Properties of Cement Mortar. Construction and Building Materials, 29, 241-245. http://dx.doi.org/10.1016/j.conbuildmat.2011.10.047 